\title{
RESTRUKTURISASI KREDIT TERHADAP DEBITUR AKIBAT WANPRESTASI KARENA DAMPAK PANDEMI COVID-19
}

\author{
I Made Rai Sukerta, I Nyoman, Putu Budiartha, Desak Gde Dwi Arini \\ Fakultas Hukum, Universitas Warmadewa, Denpasar-Bali, Indonesia \\ imaderaisukerta03@gmail.com, budiartha.fhwjurnal@gmail.com, arinidesak1966@gmail.com
}

\begin{abstract}
Abstrak
Pandemi Covid-19 di Indonesia bukan hanya berdampak terhadap kesehatan, perekonomian Indonesia juga ikut terdampak. Sektor perbankan menjadi salah satu yang terkena dampak dari pandemi ini. Restrukturisasi kredit bertujuan untuk memberikan keringanan bagi debitur dalam memenuhi kewajibannya. Kemudian aturan mengenai restrukturisasi dalam PJOK tersebut nantinya akan jadi acuan bagi bank untuk memberikan keringanan bagi debitur yang terdampak covid-19. Terdapat beberapa masalah yang dihadapi yaitu bentuk perlindungan hukum bagi debitur akibat wanprestasi karena dampak pandemi covid-19 dan kriteria debitur yang memenuhi syarat restrukturisasi kredit akibat pandemi covid-19. Menggunakan metode normatif. Benruk perlindungan hukum terhadap debitur akibat wanprestasi dapat mengajukan restrukrurisasi kredit sesuai dengan POJK. Kriteria debitur yang memenuhi syarat restrukrurisasi yaitu diberikan kepada debitur jika memang benar terdampak dari penyebaran virus corona seperti debitur yang memiliki usaha yang tergolong rentan terkena penyebaran virus corona dan usaha debitur mengalami penurunan penghasilan dan jika memang debitur memenuhi syarat tersebut maka debitur akan memenuhi persyaratan restrukturisasi dan akan direstrukturisasi setelah debitur memang benar terdampak virus corona.
\end{abstract}

Kata kunci: Kredit, Restrukturisasi, Wanprestasi.

\begin{abstract}
The Covid-19 pandemic in Indonesia has not only had an impact on health, the Indonesian economy has also been affected. The banking sector has been affected by this pandemic. Credit restructuring aims to provide relief for debtors in fulfilling their obligations. Then the rules regarding restructuring in the POJK will later become a reference for banks to provide relief for debtors who are affected by covid-19 The Covid-19 pandemic in Indonesia not only has an impact on health, the Indonesian economy is also affected. The banking sector has been affected by this pandemic. Credit restructuring aims to provide relief for debtors in fulfilling their obligations. Then the rules regarding restructuring in the POJK will later become a reference for banks to provide relief for debtors affected by Covid-19. There are several problems faced, namely the form of legal protection for debtors due to default due to the impact of the Covid-19 pandemic and the criteria for debtors who meet the requirements for credit restructuring due to the Covid-19 pandemic. Using normative methods. Benruk legal protection for debtors due to default can apply for credit restructuring in accordance with the POJK. The criteria for debtors who meet the requirements for restructuring are given to debtors if they are really affected by the spread of the corona virus such as a debtor who has a business that is classified as vulnerable to the spread of the corona virus and the debtor's business has decreased income and if indeed the debtor meets these requirements the debtor will meet the restructuring requirements and will be restructured after the debtor is indeed affected by the corona virus.
\end{abstract}

Keywords: Credit, Restructuring, Default.

\section{PENDAHULUAN}

Semenjak awaJ kemuncuJan adanya kasus virus corona di Indonesia serta merta berdampak terhadap perekonomian di Indonesia. Pasal 33 UUD NRI adalah dasar dari perekonomian Indonesia, maka pasal tersebut menunjukkan bilamana diutamakan kemakmuran masyarakat banyak, bukan hanya untuk perorangan. Pandemi covid-19 yang penyebarannya yang terjadi pada bu Ian maret 2020 di lndone ia telah mengakibatkan ketakutan yang terjadi di dalam masyarakat, adanya pandemic covid-19 ini telah menyebabkan berbagai sendi-sendi kehidupan menjadi lumpuh, tidak hanya aspek kesehatan yang kita ketahui memakan korban cukup signifikan namun juga berdampak bagi sektor perekonomian yang mengakibatkan berbagai masalah keuangan muncuJ khususnya pada sektor perbankan. Sektor perbankan menjadi salah satu yang terkena dampak. Dampak pandemi virus corona terhadap industri 
perbankan pada setiap segmennya itu berbeda-beda. Perbankan adalah segala aspek yang menyangkut tentang lembaga bank. Sedangkan Bank adalah industri yang bergerak di bidang keuangan, maksudnya kegiatan perbankan senantiasa berkaitan dalam bidang keuangan. (Ardiansyah Putra, 2020 21).

Covid-19 membawa dampak hukum untuk para pihak agar melakukan peninjauan kembali isi kontrak yang tidak sesuai lagi dengan kondisi saat ini. Dengan negosiasi para pihak dapat melahirkan bentuk-bentuk kesepakatan yang saling mempertimbangkan kepentingan rnasing-rnasing (Agus, 2008: 1)

Pandemi Covid-19 membawa pengaruh terhadap revenue atau penghasilan industri perbankan, tetapi dampaknya itu berbeda-beda pada setiap segmen nasabah. Adapun dampak yang kini dihadapi lembaga perbankan pada masa pandemi covid-19 ini diantaranya seperti risiko kredit, risiko pasar dan risiko operasional. Aki bat dari dampak covid-19 itu pada sektor perbankan mengeluarkan kebijakan terkait penundaan pembayaran kredit bagi nasabah.

Industrialisasi adalah proses modernisasi ekonomi yang mencakup seluruh sektor ekonomi yang berkaitan satu sama lain dengan industri pengolahan. Artinya, industrialisasi bertujuan meningkatkan nilai tambah seluruh sektor ekonomi dengan sektor industri pengolahan sebagai sektor utama. Maksudnya, dengan adanya perkembangan industri maka akan memacu dan mengangkat pembangunan sektor-sektor lainnya (Arsyad, 2004).

Dalam transaksi bisnis seringkali terjadi wanprestasi yang berdampak luas terhadap perencanaan bisnis sehingga dapat merugikan aspek finansial maupun non finasial seperti nama baik (goodwill) dan kepercayaan bisnis (business trust). Akibat Hukum dari wanprestasi adalah pihak yang tidak dapat melaksanakan perjanjian harus bertanggung jawab mengganti kerugian obyek yang telahdise pakati diawal (Aminah, 2020).

Agar di dalam suatu perjanjian antara bank dengan nasabah merasa tidak saling dirugikan maka OJK menerbitkan POJK 1 1/POJK.03/2020 yang mana peraturan ini lahir sebagai dampak dari adanya penyebaran wabah covid-19 yang menyebabkan debitur kesulitan untuk mernenuhi kewajibannya dalam membayar utang, peraturan ini kemudian juga dapat menjadi acuan bagi lembaga perbankan.

Terdapat penelitian yang serupa dengan penelitian ini tetapi memiliki tujuan yang berbeda seperti yang dilakukan oleh (Arya Bangbang Frisyudha, I Nyoman Putu Budiartha, Ni Komang Arini Styawati 2021) tentang Renegosiasi Sebagai Upaya Penyelesaian Wanprestasi Dalam Kontrak Bisnis Selama Masa Pandemi Covid19, (Dr. Aminah, SH, Msi.2020) Pengaruh Pandemi Covid 19 Pada Pelaksanaan Perjanjian, (Firdha Tia Aveliani 2021) Analisis Yuridis Pelaksanaan Perjanjian Kredit Perbankan Di Masa Pandemi Covid'19 ( Studi Kasus di Pt. Bpr Bkk Purwodadi).

Tujuan dari penelitian ini adalah untuk mengetahui bentuk perlindungan hukum bagi debitur akibat wanprestasi karena dampak pandemi covid-19 dan untuk kriteria debitur yang memenuhi syarat restrukturisasi kredit akibat pandemi covid-19.

\section{METODE PENELITIAN}

Tipe penelitian yang digunakan adalah studi hukum normatif dilakukan dengan metode rnengkaji peraturan perundang- undangan. Dari sisi metodologi secara ilmiah ilmu hukum normatif tata cara pengungkapannya terikat pada persyaratan logika deduktif (1 Dewa Gede Atmadja, 2018 71). Tipe penelitian yang diterapkan pada penelitian ini adalah metode penelitian hukum normatif. Metodeini mengkaji hukum dari perspektif internal yuridis baik melalui norma hukum, konsep hukum, asashukum dan doktrin hukum (Pasek Diantha, 2017:93). Pendekatan yang dipakai dalam penelitian ini adalah pendekatan undang-umdang dan konseptual serta Sumber bahan hukum rnenggunakan sumber bahan hukum primer serta sekunder. Teknik yang digunakan dalam pengumpulan bahan hukum ialah menganalisa segala buku yang berkaitan dengan permasalahan yang akan diteliti, kemudian akan disusun secara terukur dan sistematis.

\section{HASIL DAN PEMBAHASAN}

\section{Bentuk Perlindungan Hukum Bagi Debitur Akibat Wanprestasi Karena Dampak Pandemi Covid- 19}

Wanprestasi adalah belum dipenuhinya prestasi serta lalai disaat melakukan pemenuhan kewajiban seperti kewajiban debitur kepada kreditur sebagaimana yang telah disepakati pada isi dari perjanjian 
tentunya mengikat para pihak, dengan makna lain salah satu pihak ada yang dirugikan dan hal tersebut bukan dalam keadaan memaksa. (Leonora Bakarbessy,2018,41)

Timbulnya wanprestasi dikarenakan adanya suaru perjanjian yang dibuat dari para pihak, jika dalam hal para pihak melakukan cidera janji atau wanprestasi tidak dinyatakan adanya suatu perjanjian maka dari itu tidak bisa dinyatakan sebagai wanprestasi melainkan suatu perbuatan melawan hukum, mengingat pada dasarnya konsep dari wanprestasi tersebut merupakan perbuatan penyimpangan yang dilakukan oleh pihak tersebut, tentunya dengan keadaan yang tidak memaksa.

Pandemi covid-19 merupakan wabah penyakit yang menyebar keseluruh dunia, covid-19 merupakan penyakit coronavirus jenis baru yang muncul pada akhir tahun 2019, tanda-tanda dari virus ini yairu seperti batuk, bersin dan menyerang saluran pernapasan dan dinyatakan pandemi oleh WHO, karena menyebar luas ke seluruh dunia, dan menjadi masalah bersama warga dunia.

Perlindungan hukum merupakan perlindungan yang dilakukan oleh pemerintah kepada masyarakat dalam hal masyarakat yang merasa belum mendapatkan perlindungan khusus serta memerlukan rasa keadilan dalam hidup berbangsa dan bernegara. Di dalam buku ini Moch. lsnaeni berpendapat perihal perlindungan hukum, terdapat dua (2) perlindungan hukum adalah perlindungan hukum eksternal serta internal. Perlindungan hukum eksternal bermula atas administrator kepada regulasi berbenruk aturan perundang-undangan. Perlindungan hukum disiapkan oleh pembuat undangundang buat mengesrimasi ketidakadilan yang dirasakan terhadap salah saru pihak saat melakukan kontrak serta mengestimasi terdapatnya eksploitasi yang dicoba oleh salah saru pihak yang memiliki bargaining position yang lebih unggul dari pihak lainnya. Perlindungan hukum internal pada hakikatnya bertujuan guna melindungi kebutuhan para pihak yang dibentuk bersumber pada kata seruju, diruangkan ke dalam klausul-klausul kontrak. Perlindungan hukum internal bisa terbuat dengan benar jika para pihak di sebut memiliki bargaining position yang seimbang. penempatan tawar yang seimbang dari para pihak bisa melindungi keperluan para pihak secara layak serta bisa membentuk kontrak yang tentunya sehat. Pihak-pihak dalam hal melakukan kontrak sesungguhnya telah membuat perlindungan hukum internal diciptakan secara mandiri berfokus pada kata setuju. (Subekti, 2019 60)

Terpaut dengan kasus kredit macet dimana nasabah maupun debitur hadapi kesusahan buat melakukan kewajibannya dalam membayar hutang bisa melaksanakan restrukturisasi kredit pada bank ataupun industri pembiayaan bersumber pada syarat Pasal 2 POJK,spesialnya pada Pasal 2 Ayat (I). Buat debirur yang penuhi persyaratan diatas hingga debitur memperoleh restrukturisasi kredit ataupun pernbiayaan, yang tertuang pada Bab ill Peraturan Otoritas Jasa Keuangan tersebut mengatur tentang restrukturisasi kredit ataupun pembiayaan.

Selain berfungsi mengurangi beban dari debitur, restrukturisasi kredit pula melindungi likuiditas dari suatu bank, melihat suasana perekonomian di tengah pandemi semacam ini. Kebijakan ini ditimbulkan mengingat nasabah belum bersedia membayar hutang serta kewajiban nasabah kepada bank sebagai timbulnya dampak virus corona terkait melemahnya perekonornian rnasyarakat, hal tersebut sebagai cara yang dikeluarkan pemerintah untuk menjaga kehidupan masyarakat saat adanya panderni terhadap timbulnya masalah yang terjadi di sektor perbankan. Dengan dikeluarkannya kebij akan ini , maka debitur dapat mengajukan penangguhan pembayaran atau melakukan negosiasi kepada bank jika ia terdampak dari pandemi covid-19 dimana tujuannya adalah unruk meringankan kewajiban debirur dalam hal pembayaran utang.

\section{Kriteria Debitur yang Memenuhi Syarat Restrukturisasi Kredit Akibat Pandemi Covid-19}

Kredit ialah kondisi penyerahan baik berupa uang, benda, maupun jasa dari salah satu pihak seperti pihak pemberi kredit terhadap pihak yang satunya lagi bisa disebut sebagai pihak yang menerima kredit,dengan kesepakatan bersama buat bisa dituntaskan dengan kurung waktu yang ditentukan diiringi terdapatnya imbalan atas bonus pokok tersebut (Andrianto, 2020: 2).

Restrukturisasi kredit dilakukan sebagai upaya untuk penyelamatan kredit yang bermasalah yang dapat dilakukan melalui tiga cara yaitu penjadwalan kembali, penataan kembali, serta reconditioning. Sebagai contoh yaitu perpanjangan jangka waktu, penurunan suku bunga dan lain sebagainya. Restrukturisasi kredit bisa dilaksanakan jika nasabah mempunyai perilaku baik. Nasabah berperilaku baik dalam menuntaskan kredit yang bermasalah bisa ditentukan dari keinginan serta keahlian mernenuhi kewajiban dalam wujud sikap nasabah, sebagai berikut

1. Nasabah harus sanggup untuk diajak berbincang-bincang terkait perihal menuntaskan kreditnya

2. Nasabah bersedia memberikan informasi keuangan yang benar 
3. Nasabah harus memberi izin kepada pihak bank dalam hal melaksanakan pengecekan keterangan keuangan dan

4. Nasabah turut berbaur dalam program pengamanan kredit macet serta melaksanakan cara-cara yang dikeluarkan dari pihak bank (Trisadini 2017:206-208)

Dalam perihal kriteria debitur yang penuhi ketentuan restrukturisasi kredit akibat pandemi covid- 19 ialah diatur dalam POJK 11/ POJK. 03/ 2020, pada Bab III mengendal ikan tentang restrukturisasi kredit ataupun pembiayaan Pasal 5 serta Pasal 6. Di dalam Pasal 5 Ayat (1) memastikan mutu kredit atau pun pembiayaan yang direstrukturisasi diresmikan mudah sernenjak dicoba restrukturisasi. Perihal ini adalah salah satu upaya Relaksasi Kredit dikala pandemi covid- 19, Pas al 5 Ayat (2) bank bisa memberikan restrukturisasi kredit dikala debitur mengajukan kredit kepada bank saat sebelum maupun sehabis terbenruknya pandemi covid- 19 tetapi dalam perihal debitur mengajukan kredit saat sebelum terjaLin pandemi covid-19 mutu kredit ataupun pembayaran wajib dinyatakan mudah. Restrukturisasi kredit tersebut berlaku untuk usaha kecil menengah (UKM) serta tercantum UMKM juga, ayat tiga dirnana kredit buat Bank Perkreditan Rakyat serta Bank Perkreditan Rakyat Syariah bergantung pada perlakuan akuntansi masing-masing bank, Pasal 6 poin a, diberikan terhadap debitur yang penuhi ketentuan ialah debitur terserang akibat pandemi covid- 19 tercantum debitur usaha mikro, kecil, serta menengah, Pasal 6 poin b, akan direstrukturisasi sehabis nasabah dinyatakan terserang akibat timbulnya pandemi covid- 19 tercantum nasabah usaha mikro, kecil, serta menengah. Bersumber pada ketentuan Pasal 10 Peraturan OJK Republik Indonesia diatas tersebut masa berlakunya hingga dengan bertepatan pada 31 Maret 2021.

Terkait dengan panderni covid-19 yang belum berakhir OJK kembali memunculkan POJK No.48 /POJK.03/2020 guna merubah aturan POJK No.I I/POJK.03/2020. Adapun ketentuan-ketuan yang menyebutkan mengenai restrukturisasi kredit dalam ayat tiga (3) diubah serta ditambahkan menjadi tiga (3) ayat, supaya dalam hal relaksasi lebih jelas lagi aturan sehingga selaku nasabah yang ingin melakukan relaksasi terkait kurang mampu memenuhi kewajibannya tidak merasakan keraguan lagi karena aturannya sudah lebih jelas.

Tujuan dibuatnya aturan tersebut adalah mempertimbangkan bahwa penyebaran covid-19 masih terjadi baik secara global maupun secara nasional yang tentunya berakibat bagi debitur serta meminirnalisir resiko kredit macet, maka dari itu dibuat suatu peraturan oleh Lembaga otoritas jasa keuangan untuk mengantisipasi dan mengoptimalkan kinerja bagi perbankan serta dapat menjaga stabilitas dan mampu meningkatkan pertumbuhan ekonomi, namun harus mengutamakan dan mempergunakan prinsip kehati-hatian.

Sebagai contoh PT. BPR Sadana Utama Bali membuat kebijakan terkait restrukturisasi sesuai Standar Operasional Prosedur yang dibuat, karena adanya pandemi yang terjadi, kebijakan tersebut dibuat dalam rangka melindungi kredit nasabah yang memang tergolong terkena wabah virus corona serta dalam hal mendukung dan mengoptimalkan kinerja dari perbankan, utamanya fungsi intermediasi serta kestabilan dari suatu sistem keuangan menjadi terlindungi selama masih ada dinyatakan virus corona ini. Lalu mendukung pertumbuhan ekonomi hams dibentuk suatu kebijakan mengacu pada POJK Nomor 11 /POJK.03/2020, kebijakan ini diterapkan dengan tetap memperhatikan prinsip kehatihatian.

Untuk itu pada PT. BPR Sadana Utama Bali menetapkan Standar Operasional Prosedur restrukturisasi kredit dampak penyebaran pandemi covid-19 yang dapat dijadikan pedoman bagi calon nasabah atau nasabah yang sudah terdaftar pada PT. BPR Sadana Utama Bali.

Adapun maksud dan tujuan dari kebijakan Restrukturisasi kredit pada PT. BPR Sadana Utama Bali yaitu:

\section{l. Maksud}

a. Sebagai bentuk mengoptimalkan suatu kinerja perbankan utamanya BPR sebagai sifat intermediasi berguna dalam hal melindungi stabilitas keuangan serta membanru peningkatan ekonomi akibat perkembangan penyebaran Covid-19

b. Menerapkan manajemen risiko BPR dan

c. Menerapkan prinsip kehati-hatian dalam pengelolaan BPR.

\section{Tujuan}


a. Mempunyai tindakan yang tentunya semakin luas, sehingga penyusunan pembiayaan tergolong tidak lancar dengan mudah dapat dikendalikan dan mempermudah pemberian pembiayaan baru terhadap nasabah

b. Mewujudkan suatu countercyclical dari meluasnya virus corona sehingga dapat menopang serta mengoptimalkan kinerja perbankan diutarnakan tujuan intermediasi, rnelindungi kestabilan sistem keuangan dan mewujudkan kemajuan ekonomi

c. Munculnya penerapan kebijakan bisnis yang tentunya lebih jelas, terkendali dan ternilai

d. timbulnya la ngkah dan tujuan yang semakin jelas terutama kepada manajemen dalam pelaksanaan tugas dan cara guna menetapkan standar operasional bank.

e. Dapat memitigasi risiko pembiayaan dan menentukan langkah yang tepat dalam mengendalikan risiko pembiayaan dengan memperhatikan prinsip kehati-hatian dan

f. Memudahkan pengendalian risiko pembiayaan yang akan muncul akibat penyebaran Covid-19.

Bentuk-bentuk Restrukturisasi Berdasarkan Standar Operasional Prosedur PT. BPR Sadana Utama Bali yaitu

a) Penyesuaian suku bunga

b) Penyesuaian jangka waktu dan

c) Penangguhan pembayaran pokok.

Adapun sektor ekonomi debitur yang tergolong memang terdampak karena adanya pandemi

Covid-19 yaitu:

1. Pariwisata

2. Transportasi

3. Perhotelan

4. Industri

5. Perdagangan

6. Pertambangan

7. Pertanian

8. Jasadan

9. sektor lainnya sepanjang hasil dari penilaian yang ditentukan bank bagi debirur yang tergolong terkena imbas atas timbulnya wabah Covid -19 .

\section{SIMPULAN DAN SARAN}

\section{Simpulan}

Dari paparan hasil penelitian dapat disimpulkan bahwa:

1. Bentuk perlindungan hukum bagi debitur yang terdarnpak penyebaran wabah covid-19 yaitu debitur dapat mengajukan restrukturisasi dan debitur mendapatkan restrukturisasi atau pembiayaan sesuai dengan Pasal 5 dan Pasal 6. kebijakan ini timbul karena memang di masa pandemi seperti ini banyak nasabah yang tidak marnpu melunasi kreditnya karena banyak sekali adanya kejadian PHK massal dan rnengakibatkan penghasilan masyarakat menjadi menurun, karena menang daerahnya tergolong zona merah dan pastinya menerapkan pembatasan sosial berskala besar.

2. Kriteria debitur yang rnernenuhi syarat restrukturisasi kredit akibat pandemi covid-19 akan dinilai berdasarkan kualitas kredit si debitur dimana jika sebelum ada pandemic covid-19 debitur telah dinyatakan wanprestasi maka menjadi perti mbangan bagi kreditur unruk dapat atau tidak dalam memberikan restrukturisasi kredit.

\section{Saran}

Berdasarkan hasil penelitian, peneliti memberikan beberapa saran, sebagai berikut:

1. Kepada Pemerintah, darnpak dari panderni covid-19 berpengaruh secara langsung maupun tidak langsung terhadap perekonomian masyarakat, perlindungan hukum bagi masyarakat seharusnya tidak berfokus terhadap nasabah yang melakukan kredit pada perbankan, dibutuhkan juga perhatian dan upaya lebih lagi bagi pemerintah unruk memberikan perlindungan bagi masyarakat lain yang terdampak dari pandemi covid-19 dengan demikian sehingga akan ada keadilan dalam perlindungan terhadap masyarakat, dari kebijakan pemerintah.

2. Kepada pihak Bank dalam hal memberikan restrukrurisasi kepada debirur harus memperhatikan itikad baik dari si debitur, sehingga pemberian restrukrurisasi tersebut tepat sasaran dan kepada pihak debitur yang tidak beritikad baik untuk melakukan restrukrurisasi maka harus siap menerima sanksi sesuai dengan ketenruan hukum yang berlaku. 


\section{DAFTAR PUSTAKA}

Andrianto. (2020). Manajemen Kredit. CV Penerbit Qiara Media. Pasuruan Jawa Timur.

Aminah. (2020). Pengaruh Pandemi Covid 19 Pada Pelaksanaan Perjanjian. Diponegoro Private Law Review, 7(1), 650-656.

Atmadja, I. D. G., \& Atmadja, I. D. G. (2018). Teori-Teori Hukum. Setara Press.Malang.

Aveliani, F. T. (2021). Analisis Yuridis Pelaksanaan Perjanjian Kredit Perbankan Di Masa Pandemi Covid'19 ( Studi Kasus di Pt. Bpr Bkk Purwodadi). Fakultas Hukum Universitas Muhammadiyah Surakarta.

Bakarbessy, L., \& Anand, G. (2018). Buku Ajar Perikatan. Zifatama Jawara.Sidoarjo.

Diantha, \& Pasek, I. M. (2017). Metode Penelitian Hukum Normatif dalam Justifikasi Teori Hukum. Prenada Media Group Jakarta.

Lincolin, A. (2004). Ekonomi Pembangunan. STIE YKPN.Yogyakarta

Putra, A., \& Saraswati, D. (2020). Bank Dan Lembaga Keuangan Lainnya. CV. Jakad Media Publishing. Surabaya.

Subekti, Veronika, \& Lestari, N. S. (2020). Perlindungan Hukum Bagi Konsumen Rumah Tapak Dalam Kontrak Jual Beli Berdasarkan Perjanjian Pengikatan Jual Beli. Cv Jakad Media Publishing, Cv Jakad Media Publishing Graha Indah E-11. Gayung Kebonsari.Surabaya.

Usanti, T. P., \& Shomad, A. (2017). Hukum Perbankan. Kencana Depok.

Frisyudha, A. B., Budiartha, I. N. P., \& Styawati, N. K. A. (2021). Renegosiasi Sebagai Upaya Penyelesaian Wanprestasi Dalam Kontrak Bisnis Selama Masa Pandemi Covid19. Jurnal Konstruksi Hukum, Vol. 2, No.2. 